\title{
Megalithic Culture and Its Post Visualization: A Short Review on Findings From Archeological Site and Local Tradition in Indonesia
}

\author{
Lutfi Yondri $^{1}$, Nina Herlina ${ }^{1}$, Mumuh M. Zakaria ${ }^{1}$, and Mundardjito ${ }^{2}$ \\ University of Padjadjaran ${ }^{1}$, University of Indonesia, Indonesia ${ }^{2}$
}

\begin{abstract}
Long span of megalithic culture development in Indonesia can be seen from its materials remain. It does appear on the sacred and on the profane form. The aim of this article is trying to describe about the megalithic visualization. Some of megalithic aspects such as shape, size, and its material had been applied. Megalithic culture in Indonesia is generally found on small size, while the large size is only found in certain locations. It can be concluded the visualization of megalithic culture in Indonesia is no longer in accordance with its etymology as cultural that uses large stone, because small stone and wood are also used as source.
\end{abstract}

Keywords: culture, megalithic, visualization, tradition, and material

\section{Introduction}

The dynamic of Indonesian cultural during the prehistoric period had been exhibited on several steps of it development in Indonesia. The prehistoric remains that had been found can be classified into three categories such as hunter-gather, agriculture and the era of skill in metallurgy. Especially in agricultural era produced. It was one of the specific cultures called as the megalithic culture, which was symbolized by huge stones (Ayatrohaedi, 1978, p. 103). At last, as a tradition, it had been changed and visualized in several kinds of source or material for building it monument.

Based on archaeological findings, it can be concluded that the megalithic tradition is one of the main traditions ever existed. It was called the main tradition because that culture has spread almost in every area, and able to expand within a short time since its first appearance when agriculture was first known.

The arrival of megalithic culture in Indonesia according to Heine Geldern, was grouped in two waves. The first wave, known as the Old Megalithic culture, presumably extended during the Neolithic Period, between 2500-1500 BC, whereas the second wave called the New Megalithic culture, was presumed to emerge about the early first millennium BC. The megalithic culture had come to Indonesian area by the Austronesians people who brought the square pickaxe cultures (Geldern, 1945, pp. 148-149).

From Heine Geldern's point of view it can be assumed that the arrival of megalithic culture in Indonesia was caused by the cultural migration or human migration to Indonesia in the past. This migration is that some experts concluded out from Asia main land through Taiwan, and then arrived in Indonesia, but it didn't occur

Lutfi Yondri, Magister Archaeology/Drs, M. Hum (Magister Humanities), .Faculty of Cultural Science, University of Padjadjaran, Indonesia. 
on Geldern chronology. Based on the views expressed by Blust (1976), Belwood (2000), Tanudirjo (2012) concluded the Austronesian up and growing in Indonesia through five stages. Phase $\mathrm{I}$ is the stage of the migration of farmers from southern China reached Taiwan (5000 years BC), Phase II, migration from Taiwan to the Philippines (2500 BC), Phase III, the migration from the Philippines to the south and southeast (towards 2000 BC), Phase IV, migration from North Maluku to the south and east (2000 BC), and the phase V migration of northern Papua westward and eastward (Tanudrijo, 2012). According to Munandar (2012) when the migration was rarely done, and Austronesia people had settled and steady in some areas of Southeast Asia, there is an opportunity to further develop the culture better. Based on the artifacts, it can be interpreted to mean that between $5 \mathrm{BC}$ untill $2 \mathrm{AD}$, there is a form of culture that is based on intelligence that was later known as the Dong Son culture (Munandar, 2012).

Related with the interpretation about stages and when the Austronesian settled in Indonesia, till now no artifact also archeological site had chronology like Geldern's says. Numbers of archeological site with megalithic remain such as upright stone (Menhir), dolmen, stone terraces, etc. are coming from later period. According to Sutaba (1991) with his statement as megalithic culture in Indonesia had developed around late prehistoric era or paleometalic period, but it doesn't support by any kind of data and absolut dating or chronology. Prasetyo (2013) tried to count several megalithic site in Indonesia, and found that all of site are coming from long time after Geldern's chronology, such as:

1. Hiligeo (Nias): cal. 15-10 AD

2. Tundrumbaho (Nias): cal. 15-17 AD

3. Guguk Nuang (West Sumatra): cal. 10-13 AD

4. Bukit Batu Larung (Jambi): cal. 10-13 AD

5. Bukit Arat (Jambi): cal. 7-11 AD

6. Dusun Tinggi (Jambi) cal. 4-7 AD

7. Renah Kemumu (Jambi): cal. 11-13 AD

8. Banua Keling 1, 2, 3, 4 (South Sumatra): cal. 13-17; 11-13; 7-10; 3-6 AD

9. Tebat Gunung (South Sumatra): cal. 11-14 AD

10. Pajar Bulan 1 dan 2 (South Sumatra): cal. 10-13 and 7-12 AD

11. Pasir Angin 1 dan 2 (West Java): cal. 9-10 and 10-11 AD

12. Kidangan (East Java): cal. 15-17 AD

13. Krajan Bayeman (East Java): cal. 6-11 AD

14. Pedaringan (East Java): cal. 10-14 AD

15. Dawuhan (East Java): cal. 7-9 AD

16. Doplang (East Java): cal. 13-15 AD

17. Woloan 1, 2, and 3 (North Sulawesi): cal. 4-7; 8-10; 7-9 AD

18. Tatelu 1 and 2 (North Sulawesi): cal. 4 SM BC - Early Century and 11-14 AD

New chronology about megalithic remain is coming from Gunung Padang site (West Java) from carbon dating analysis had known, that site was built around 117 until 45 BC (Yondri, 2015). All of site chronology the author thinks can be used as the adding data in interpretation about when the megalithic culture was arrived and developed in Indonesia.

With the extent of development, megalithic cultural values had emerged among various cultural contexts. The emergence of megalithic cultural values in multi contexts certainly had the implication of the material that 
was used. With the limit of physical environment as medium of material provider, visualization of megalithic cultural values would not be relied upon one single kind of material but also using other materials. In this case, material for visualization of megalithic cultural values was no longer held its definition "mega" meaning big or huge, and "lithos" meaning stone (Soejono, 1984, p. 205). Smaller sized stones and other materials such as wood, also took an important part in the cultural appearance of object. Therefore, in this study, the author does not hold on the standard definition of the word megalithic, but tries to study it based on the material or element that were used in visualizing megalithic cultural values.

Loofs, in his book Element of the Megalithic Complex in South East Asia (1967), has called the megalithic culture as "La plus grande enigma de la prehistoire", or greatest riddles. Pronouncement by Loofs here about, meaning of the megalithic culture together with the grouping provided by Geldern is difficult too.

In reality, the meaning of megalithic was not always connected with huge stones. The deeper meaning of megalithic cultures has been suggested by van der Hoop (1938) and Wagner (1962). Van der Hoop said that megalithic objects are not always made of huge stones, but sometimes using smaller stones. If the people or community in a certain area could not find the right stones to make a building, then they used wood to substitute them (Hoop, 1938, p. 98). Megalithic objects like wooden statues, which are found in Indonesia, are rarely above 200 years old. Although having various forms, these statues illustrated magical and supernatural elements. For example, the find from Luang Semata Island, between Timor and Tanimbar illustrated an ancestor figure (Claire Holt, 1976: 26). F. A. Wagner (1962) referred to megalithic culture from its ceremonial activities aspects. In his book which is titled Indonesia, the Art of an Island Group, he said that the megalith which is up to now understood as huge stones, in some places using smaller stones and other materials like wood, should also be classified as megalith, if those objects used for a certain sacred objective, like the worshiping of an ancestors spirit.

From the basic understanding mentioned by van der Hoop and Wagner, megalithic description could also be applied to other areas with certain specifications and several concepts of megalithic culture could be more understood or explainable. These explanations do not only include concept of values but also the spread of the product of material, like using material such as wood, for the building megalithic monuments, either for a sacred or a profane objective.

Based on those mentioned above it could be summarized that the visualization of megalithic cultural value with various materials represented a concrete form a symbolic system. Because the existing of megalithic cultural community underwent changes and development, therefore megalithic object also follow the changes of community and its environment. In this case, monument or object of megalith is reflecting their time and space in the past (Criado, 1991: 80).

\section{Emerging Selection of Alternate Element}

In such a culture, we often found cultural concept with similar root in several areas. Variety would be happened in shape/form or element, which was chosen to be used. On this matter one cultural value could change structurally and how was efficiency of environment resources and how did adaptive pattern form their material culture. Theoretically, men need to survive in nature, which according to Sumarwoto (1994), consisted of: (1) basic need of physical survival; (2) basic need of human survival; and (3) basic need to choose.

From the three different basic needs mentioned above, which was connected directly to cultural issues is the basic need to choose. To fulfill the basic need, the ability to choose is not only to fulfill physical survival, 
but also to express its culture (Sumarwoto, 1994, pp. 62-64). Therefore, basic needs to factor of choose exerted on emerging material culture form one culture. Then, all of that are making the community and culture not with standing in some characteristic culture. From that matter, three factors influencing each other could be desired (Soejono, 1987, p. 31).

Likewise megalithic cultural tradition, basically remains of megalithic culture accumulated on one site was part of a residential region in a holistic way in the past. Besides megalithic site, there were also other variables in that region such as dimension of thought, landscape, dwelling place, wet/dry rice field, water, and material resources and so on. From ecological view, megalithic sites were also one of part of settlement in that dimension human/people were able to visualize their cultural values with various symbolic systems which have mutual agreement according to resources provided on their settlement. Therefore visualized forms of the same root of cultural values with different will emerge different visualization. The difference would happen on the basic of material that as used, because an environment can limit in usual resources to make monument with similar cultural values in another area.

As described above, the in the course of a long history of development, the spread of megalithic cultural tradition has undergone cultural dynamics. This dynamics belongs to a system of thought which occurs in various contexts, values of concepts those exist in megalithic cultural tradition undergoing various changing on their visualization. On certain areas megalithic cultural tradition community used wood and smaller stones.

The changing material visualization in megalithic cultural values as main features can be looked through several aspects such as the cult instrument means, burial means, and a profane monument.

\section{Some Aspect in Continual Visualization}

\section{The Cults Instruments}

The worshipping of ancestors spirit indicated by the monuments built, was one of the characteristics of megalithic life, which is able to extend through endless time. Even in several places in Indonesia, the evidences can be found up till now. In that cultural progress, various values and material shifting happened. Monumental shapes that were used as worshipping ancient/ancestor spirits instruments can be classified chronologically. Earlier, the megalithic objects that were considered as symbol of the death were menhir or long-shaped stones that are vertically built (Soejono, 1984, p. 321). In the next development, the position of menhir was replaced by a simple stone statue, which was called a megalithic statue or a Polynesian type statue. Generally, wooden statues called by westerners as primitive art objects, are particular statue, which are connected with worship (cult object). The statue is that appearance could evoke empathy between the worshipper and the object of worship.

In several places (areas) those statues were not just made from stone material, but also made of wood. Traditions of using stones or wooden statues as ancestor magical elements context (ancestral poles) are still known at several local ethnic group (tribe) such as Sapundu (Dayak in Borneo), Mbis (Asmat in West Papua), and Ai Tos (Timor). One of the examples of progress can be seen on Manene Solemn (ceremony) at Tana Toraja (South Celebes) as worshipping instruments in ceremony wooden statue are built, which they called Tau-Tau. By the Tana Toraja community (especially on community with Auk Todolok belief) Tau-Tau is considered as statues as concrete forms of ancestor spirits. At given times those statues are dressed and given sacrifices. 
Cult of ancestor spirits, as a matter of fact is still a belief among isolated tribal communities in Indonesia until now, i.e. the Dayak tribe (Borneo), the Tajio (Middle Celebes), the To Pembuni and To Seko (South Celebes), the Asmat (West Papua), the people of Nias (Sumatra), and so on.

The belief in ancient spirits who occupying their surroundings, that had been appeared in the cult ceremonies of worshipping ancestor's spirits conducted by the Dayak community, in Kalimantan. They made wooden statues (hampatong and parekan), which were considered as concrete form of ancestor spirits. Statues are built in the front yard and on the balcony of the house ( $b$ 'tang) (Jan B. Ave \& Victor T. King, 1986, p. 48).

Some tribes in Indonesia actually show the cult of ancestor worship that uses materials other than stones, like wood. This matter cannot be separated from the megalithic concept that already existed, though that monument was not made of a huge stone. With these data existence of the development of megalith cultural value can be seen. The cult monuments for the ancestor spirits that are made of stones then are replaced by another material.

The changes in the material used to build the megalithic monument was also adapt to the availability in the environment where the monument was built. At several locations in the western part of Java island, the stone terrace as a megalithic site is built by stone blocks (columnar joint), slabs (sitting joint), boulders, or combination of slabs and boulders. Among others found on stone terrace of Gunung Padang site (Cianjur) which was used the stone blocks, Lebak Cibedug (Banten) by stone boulders, Arca Domas (Bogor) by stone slabs, and Hululingga (Kuningan) which constructed from the combination of slabs and boulders stone.

\section{Burial Tradition}

Like the cult/worshipping aspect, burial processes also show the shift of the use of material, although the making of burial case still comprises megalithic cultural values. At several places though hard to determine claim the exact date burial cases generally were made from stones. Burial cases are named according to local terms like waruga, kalamba, pandusa, etc.

Besides using stone as basic material for the making of megalithic burial, they also used wood. The use of wooden material as a burial case can be seen at later times, particularly in megalithic burial process at an advanced level or precisely at communities who are still having megalithic beliefs concept, like the Toraja, and Dayak. In such community, burial case made of wood comprises two parts like a stone burial case, a case, and a cover.

So for the technical making wooden coffin was applied similar technique as the making of sarcophagus, waruga and so on. An example of a wooden coffin was the sandung, which was used by the Dayak community in Kalimantan. The technical making of the sandung is similar to the making of sarcophagus. Sandung was made from a huge chopped wood. On one part the hollowed part was made according to the size of the body. Then after the body was put in, the wood was covered like original wood (Kartawinata, 1993, p. 112). The form of burial was called the primary burial system. At Dayak community, sandung also means as secondary burial, where the bones/skeleton of the dead in one family are put in together in one sandung, and then placed in the Balai Anting or above the front door of the house.

Here can be seen that after the era of using stones as burial case, later the stone is replaced by wood. However, a question arises whether the wooden burial case represents other form of megalithic burials like sarcophagus, and stone coffin, or the other way round. Because van Heekeren ever proposed that people who came to their places using boat might spread the sarcophagus and if they're any deaths, then they move to 
island. They made coffin from wood with resembled a boat. Then, those materials are replacing by stones (Soejono, 1984, pp. 130-131).

\section{Profane Monument}

Besides being used as material to build sacred monuments, wood was used to make profane objects which were represented the megalithic tradition. One of them is a rice-pounding mortar, generally found in Kalimantan (Jan B. Ave \& Victor T. King, 1986, p. 32). That matter can be described as other form of stone mortars in other districts in Indonesia. Like the stone mortar, they use centrifugal process to make the wooden mortar. The wood is cutting down with subtractive method as a basin, on the top were made a hollow or more.

The emergence of mortar in human life, either made of stone or wood, actually could not be separated from the ability of human to produce raw material that they need in daily life, like pounding rice or produce other materials such as medicine. It can be concluded here that wooden mortar was other form of stone mortar. This form in later tradition might happen because material was limited or practical reasoning.

\section{Summary}

From that explanation it is clearly shown that in megalithic cultural tradition, elements that were used to build monument were not only made from the huge stones, but also other material like wood. Material dynamic in megalithic visualized values in various form of elements, certainly could not be separated from factors within and around human life. Election of element because practical reasons and possibility on producing elements into forms that wanted was abstract factor that rive only in human mind. Whereas environmental limitation for visualizing certain cultural values, would be enforcing human to search another alternative so that cultural objects those needed could be produced.

In the long history of progress and divergence of megalithic, the megalithic values would brought and emerge by human believer in various kinds of settlements (place or position). At the area that provided stone elements the cultural values would arise in conformity with their definition. Although at the area lack of stone, their cultural norm would arise in different elements. And there was no limitation of possibilities that in several areas stone elements and other element were used together.

This study actually brought up to extend research at certain areas which are still perform megalithic cultural tradition values, but lack of stones resources, so in the formation of culture, the materials are dominated by other elements like wood. There are ways of knowing about material culture and its relation with archaeological data, especially in megalithic tradition on several outlying district in Indonesia where we cannot find a stone megalithic monument but at the place we can find a continuity of megalithic norms.

\section{Acknowledgments}

The author would like to express my appreciation to Prof. Dr. R. P. Soejono for his kindness to teach me everything about prehistoric science during studied archeology at Indonesian University for the graduate and postgraduate level. Also for Dr. Sajidin, M. Ag (English Department, UIN, Bandung), who had corrected my article in English.

\section{References}

Ave, Jan B., \& Victor T. King. (1986). Borneo, people of weeping forest: Tradition and change in Borneo. Leiden, Netherlands: National Museum of Ethnology. 
Ayatrohaedi, dkk. (Ed.). (1978). Kamus Istilah Arkeologi. Jakarta. Proyek Penelitian Bahasa dan Sastra Indonesia dan Daerah, Depdikbud.

Criado, F. (1991). We, the post-megalithic people.... In I. Hodder (Ed.), The meanings of things, material culture and symbolic expression. One World Archeology.

Carmichael, D. L, \& Jan H. (1994). Sacred sites, sacred places. One World Archaeology. Routlgedge. London and New York.

Errington, S. (1994). Unravelling Narratives. In P. Taylor (Ed.), Fragile tradition: Indonesian art in jeopardy(pp. 139-169). Honolulu: University of Hawaii.

Geldern, Von H. (1945). Prehistoric research in the Netherland indies. In P. Honig and F. Verdoorn (Eds.), Science and scientists in The Netherland indies.

Geldern, Von H. (1974). The archaeology and art of Sumatra. In E. M. Loeb (Ed.), Sumatra, its history and people.

Hodder, I. (1991). The meanings of things, material culture and symbolic expression. One World Archeology.

Holt, C. (1976). Art in Indonesia: Continuities and Change. Ithaca : Cornell University Press.

Hoop, van der. (1932). Megalithic remains in South Sumatra. Translation by Whilliam Shirlaw. Zutphen.

Kartawinata, A. M. (1993). Masyarakat Punan di Kalimantan Barat. In Dalam Kontjaraningrat, dkk (Ed.), Masyarakat Terasing di Indonesia. Jakarta: PT. Gramedia Pustaka Utama.

Loofs, H. E. (1976). Element of the megalithic complex in South East Asia. Canberra: Australian University Press.

Prasetyo, B. (2012). Budaya Megalitik Indonesia: Hasil Penelitian dan Permasalahannya. Makalah. Evaluasi Hasil Penelitian Arkeologi. Solo, 3-7 September 2012.

Prasetyo, B. (2015). Megalitik Fenomena Yang Berkembang di Indonesia. Kerjasama Kementerian Pendidikan dan Kebudayaan dan Galang Press. Yogyakarta: Galang Press.

Soejono, R. P. (Ed.). (1984). Jaman Prasejarah di Indonesia. Sejarah Nasional Indonesia I. Jakarta: PN. Balai Pustaka.

Subagya, Rahmat. (1981). Agama Asli Indonesia. Jakarta: Sinar Harapan dan Yayasan Cipta Loka Caraka.

Sutaba, I M. (1996). Dinamika Dan Kepribadian Bangsa Yang Tercermin dari Tradisi Megalitik di Indonesia. Dalam Jurnal Arkeologi Indonesia, No. 2. Jakarta: Ikatan Ahli Arkeologi Indonesia.

Sumarwoto, O. (1994). Ekologi, Lingkungan Hidup dan Pembangunan. Jakarta: Penerbit Djambatan.

Thomas, Julian. (1996). Time, culture, and identity an interpretive archaeology. London and New York: Routledge.

Wagner, F. A. (1962). Indonesia: The art of an island group. Art of the World Series.

Yondri, L. (1996). Penggunaan Kayu dalam Tradisi Budaya Megalitik. Jurnal Penelitian Balai ArkeologiBandung. Nomor 3/April/1996,13-19.

Yondri, L. (1999). Pantak/Hampatung: Media Pengagungan Arwah Leluhur dalam Kesinambungan Budaya Megalitik di Kalimantan. Jurnal Penelitian Balai ArkeologiBandung. Nomor 5/Maret/1999, 9-19.

Yondri, L. (2006). A short review on megalithic functions in Indonesia. Archaeology: Indonesian Perspective (pp. 295-302). Jakarta: LIPI Press.

Yondri, L., \& Mundardjito, dan Cecep E. P. (2012). Laporan Hasil Penelitian Arkeologi Situs Megalitik Gunung Padang. Jakarta. Pusat Arkeologi Nasional. 